\title{
KAJIAN PENDEKATAN PEMBELAJARAN STEM DENGAN MODEL PJBL DALAM MENGASAH KEMAMPUAN BERPIKIR KREATIF MATEMATIS SISWA
}

\author{
Arista Tri Anindayati ${ }^{1 *}$, Wahyudi $^{1)}$ \\ 1) Fakultas Keguruan dan Ilmu Pendidikan, Universitas Muhammadiyah Ponorogo \\ e-mail: arita27890@gmail.com
}

\begin{abstract}
Science, Technology, Engineering, and Mathematics (STEM) is an active learning approach to improve (mathematics) students' creative thinking abilities in mathematics learning. In the learning process, STEM combines four main areas, namely knowledge, technology, engineering, and mathematics. Project-Based Learning (PjBL) is a learning model that teaches concepts through a student-centered project so students can work creatively and collaboratively. The purpose of this article is to describe and provide many things related to STEM as an approach that can integrate knowledge, technology, techniques, and mathematics as well as design the implementation of STEM learning approaches with PjBL models to enhance students' creative thinking in mathematics learning. The method used is a literature review. The results of the study show that some essential competencies in mathematics learning can integrate with the STEM approach in the form of routine activity of the STEM approach in the classroom and the provision of projects to students. Thus, the implementation of the STEM approach to mathematics learning can be done in Indonesia to prepare quality human resources and be ready to face challenges and competitions in the industrial revolution era 4.0 in the 21 st century.
\end{abstract}

Keywords: STEM, PjBL, Creative, Mathematics

\begin{abstract}
Abstrak
Science, Technology, Engineering and Mathematic (STEM) merupakan sebuah pendekatan pembelajaran yang efektif untuk meningkatkan kemampuan berpikir kreatif matematis siswa pada pembelajaran matematika. Dalam proses pembelajaran, STEM menggabungkan empat bidang utama yaitu pengetahuan, teknologi, teknik dan matematika. Project Based Learning (PjBL) merupakan model pembelajaran yang mengajarkan konsep melalui sebuah proyek yang berpusat pada siswa agar siswa dapat bekerja secara kreatif dan kolaboratif. Tujuan dari penulisan artikel ini adalah untuk memaparkan dan memberikan gambaran beberapa hal yang berkaitan dengan STEM sebagai pendekatan yang dapat mengintegrasikan pengetahuan, teknologi, teknik dan matematika serta rancangan implementasi pendekatan pembelajaran STEM dengan model PjBL untuk meningkatan berpikir kreatif matematis siswa pada pembelajaran matematika. Metode yang digunakan adalah kajian pustaka. Hasil kajian menunjukan bahwa beberapa kompetensi dasar dalam pembelajaran matematika dapat diintegrasikan dengan pendekatan STEM berupa aktifitas pembiasaan pendekatan STEM di kelas dan pemberian projek kepada siswa. Dengan demikian pengimplementasian pendekatan STEM pada pembelajaran matematika dapat dilakukan di Indonesia dalam rangka mempersiapkan sumber daya manusia yang berkualitas serta siap menghadapi tantangan dan persaingan di era revolusi industri 4.0 di abad 21 ini.
\end{abstract}

Kata Kunci: STEM, PjBL, Kreatif, Matematis

\section{PENDAHULUAN}

Perkembangan IPTEK pada era revolusi industri 4.0 di abad 21 semakin tak terbendung. Hal tersebut berimbas pada tantangan dan persaingan global di setiap negara, 
khususnya Indonesia. Untuk mengimbangi hal tersebut kita dituntut untuk beradaptasi dengan cepat dengan perkembangan jaman saat ini. Oleh karena itu tentu diperlukan sumber daya manusia yang berkualitas. Dengan adanya sumber daya manusia yang berkualitas diharapkan negara Indonesia mampu untuk berkompetisi dengan negara lain.

Demi mewujudkan sumber daya manusia yang berkualitas, generasi muda tentunya juga harus memiliki beberapa kompetensi atau keahlian. Kompetensi tersebut wajib dikuasai dan dimiliki setiap manusia agar mereka mampu menghadapi kehidupan di abad 21 ini. Menurut National Education Association (2002) empat keterampilan dasar (4C) yang dibutuhkan pada abad 21 dan yang perlu dikuasai oleh setiap individu diantaranya: (1) critical thinking and problem solving, yaitu kemampuan berpikir kritis dalam menyelesaikan masalah (2) creativity and innovation, yaitu kemampuan untuk menciptakan sesuatu hal yang baru dan mempunyai inovasi (3) communication, yaitu kemampuan dalam mendengar, membaca, berbicara dan menulis dengan menggunakan berbagai media (4) collaboratios, yaitu kemampuan dalam bekerja sama dan menghargai orang lain.

Kreativitas atau kemampuan berpikir kreatif masih perlu kita tumbuhkan dan bekal itu harus ditumbuhkan sejak dini. Kemampuan berpikir kreatif merupakan kemampuan yang berhubungan dengan kreativitas yang dapat diartikan sebagai cara berpikir untuk mengubah atau mengembangkan suatu permasalahan, melihat situasi atau permasalahan dari sisi yang berbeda, terbuka pada berbagai ide dan gagasan bahkan yang tidak umum. Menurut Rhodes (1961), kreativitas adalah menganalisis empat dimensi yang dikenal dengan dengan istilah "the Four P's of Creativity" atau empat P dari kreativitas yaitu person, product, process, dan press. Pertama, kreativitas sebagai person mengilustrasikan individu dengan pikiran atau ekspresinya yang unik. Kedua, kreativitas sebagai product merupakan kreasi yang baru, asli, dan bermakna. Ketiga, kreativitas sebagai process merefleksikan keterampilan dalam berfikir yang meliputi: kemahiran/kelancaran (fluency), fleksibilitas (flexibility), originalitas (originality), dan elaborasi (elaboration). Keempat, kreativitas sebagai press adalah kondisi internal atau eksternal yang mendorong munculnya berpikir kreatif. Pendidik harus mampu mengembangkan metode yang bisa merangsang kreativitas sehingga akan menciptakan generasi yang banyak ide kreativitasnya.

Pendidikan merupakan salah satu usaha untuk menguasai kemampuan berfikir kreatif guna menghadapi kompetisi era revolusi industri 4.0 di abad 21. Upaya kongkrit yang dilakukan oleh tenaga pendidik dan pemerintah Indonesia adalah menyiapkan sebuah sistem pendidikan yang mampu menciptakan kesempatan kepada peserta didik untuk menghubungkan antara pengetahuan dan ketrampilan sehingga setiap peserta didik diharapan mampu mengembangkan kemampuan berpikir kreatifnya. Upaya tersebut dapat dilakukan dengan berbagai cara yang salah satunya dengan penyempurnaan pendekatan dan metode pembelajaran yang digunakan saat proses pembelajaran.

Sciece, Technology, Engineering, Mathematic (STEM) merupakan sebuah pendekatan pembelajaran yang efektif untuk meningkatkan kemampuan berpikir kreatif siswa. Dalam proses pembelajaran, STEM meggabungkan empat bidang utama yaitu, sains, teknologi, teknik, serta matematika dan menghubungkannya dengan kehidupan sehari-hari. Torlakson (2014) mengemukakan bahwa pendekatan dari keempat bidang ilmu tersebut merupakan kolaborasi bidang ilmu yang serasi antar masalah yang terjadi di dunia nyata. Model pembelajaran yang dapat di gunakan untuk pendekatan pembelajaran STEM ini salah satunya adalah model pembelajaran project based learning (PjBL). Model pembelajaran $\mathrm{PjBL}$ merupakan model pembelajaran berbasis proyek yang mampu memfasilitasi serta memberikan tantangan dan motivasi kepada siswa dalam mengkontruksi pengetahuannya sendiri dan mengembangkan kemampuan berpikir kreatifnya (Made Wena dalam Lestari, 2015). Model pembelajaran PjBL terintegrasi pendekatan STEM adalah salah satu inovasi pembelajaran yang dapat melatih kemampuan menemukan solusi secara 
beragam, fleksibel, terbaru, unik namun dapat diterima kebenarannya. Dengan demikian tingkat berpikir dengan model STEM PjBL mampu menjadikan pemikiran yang lebih kreatif.

Pada beberapa karya tulis hasil penelitian menunjukan bahwa pendekatan STEM dengan model pembelajaran PjBL mampu meningkatkan berpikir kreatif siswa pada pembelajaran matematika. Hal ini menjadi salah satu yang mendorong penulis melakukan kajian pustaka mengenai pembahasan tersebut. Pada tulisan ini penulis mencoba memaparkan dan memberikan gambaran beberapa hal yang berkaitan dengan STEM sebagai pendekatan yang dapat mengintegrasikan pengetahuan, tekhnologi, teknik dan matematika serta rancangan implementasi pendekatan pembelajaran STEM dengan model $\mathrm{PjBL}$ untuk meningkatan berpikir kreatif siswa pada pembelajaran matematika.

\section{METODE}

Pada penelitian ini penulis menggunakan jenis/pendekatan penelitian yang berupa penelitian kepustakaan. Penelitian kepustakaan merupakan suatu studi dengan melakukan penelaahan atau pengumpulan informasi dan data dengan bantuan berbagai macam buku, jurnal, papers, artikel, disertasi, tesis, dan karya ilmiah lainnya yang dikutip didalam penulisan proposal yang berkaitan dengan masalah yang ingin dipecahkan atau sedang dibahas (Nazir, 1988). Menurut Syaibani (2012) penelitian kepustakaan adalah segala usaha yang dilakukan oleh peneliti untuk menghimpun informasi yang relevan dengan topik atau masalah yang akan atau sedang diteliti. Penelitian kajian pustaka pada pembahasan ini bertujuan untuk menginformasikan, menganalisis, menggabungkan dan menafsirkan konsep dari hasil penelitian peneliti sebelumnya yang berkaitan erat dengan kajian yang sedang dibahas.

Metode kajian pustaka ini digunakan untuk menyusun konsep mengenai pendekatan STEM dengan model PjBL untuk untuk meningkatan berpikir kreatif siswa pada pembelajaran matematika. Adapun langkah-langkah dalam penulisan kajian pustaka ini menurut Kuhlthau (2002) adalah pemilihan topik, eksplorasi informasi, menentukan fokus kajian, pengumpulan sumber data. persiapan penyajian data, dan penyusunan laporan. Teknik analisis data yang digunakan dalam kajian ini adalah metode analisis isi. Analisis ini digunakan untuk mendapatkan inferensi yang valid dan dapat diteliti ulang berdasarkan konteksnya (Krippendorff, 1933). Dalam analisis ini akan dilakukan proses memilih, membandingkan, menggabungkan dan memilah berbagai pengertian hingga ditemukan yang relevan (Serbaguna, 2005). Untuk menjaga kekelan proses pengkajian dan mencegah serta mengatasi miss-informasi (kesalahan pengertian manusiawi yang bisa terjadi karena kekurangan penulis pustaka) maka dilakukan pengecekan antar pustaka dan memperhatikan komentar pembimbing (Sutanto, 2005).

\section{HASIL DAN PEMBAHASAN}

\section{Science, Technology, Engineering, Mathematics (STEM)}

STEM merupakan akronim dari Science, Technology, Engineering, Mathematics. Istilah STEM pertama kali diluncurkan oleh National Science Foundation AS pada tahun 1990-an. STEM merupakan pembelajaran baru dalam dunia pendidikan. Beberapa tahun ini STEM menjadi topik utama diskusi dan perencanaan pembelajaran di Amerika Serikat karena Amerika Serikat berpendapat bahwa daya saing negara tergantung pada program pendidikan yang kuat dalam mempersiapkan para ilmuwan dan insinyur yang inovatif yang akan memberikan inovasi penting untuk ekonomi yang berkembang di era teknologi ini.

STEM merupakan intregasi antara empat disiplin ilmu yaitu ilmu pengetahuan, teknologi, rekayasa, dan matematika dalam pendekatan interdisipliner dan diterapkan berdasarkan konteks dunia nyata dan pembelajaran berbasis masalah. Pembelajaran STEM meliputi proses berfikir kreatif, kritis, analisis, dan kolaborasi dimana siswa mengintregasikan proses 
dan konsep dalam konteks dunia nyata dari ilmu pengetahuan, teknologi, rekayasa, dan matematika mendorong pengembangan ketrampilan dan kompetensi untuk kuliah, karir, dan kehidupan.

Pendidikan STEM bermakna memberi penguatan praktis pendidikan dalam bidangbidang STEM secara terpisah, sekaligus mengembangkan pendekatan pendidikan yang mengintregasikan sains, teknologi, rekayasa, dan matematika, dengan memfokuskan proses pendidikan pada pemecahan masalah nyata dalam kehidupan sehari-hari atau kehidupan profesi. Honey, dkk (2014) telah mendefinisikan masing-masing empat disiplin STEM beserta perannya masing-masing yaitu :

1. Sains adalah pengetahuan yang telah terakumulasi dari waktu ke waktu dari sebuah pemeriksaan ilmiah yang menghasilkan pengetahuan baru. Ilmu pengetahuan dari sains berperan menginformasikan proses rancangan teknik.

2. Teknologi adalah keseluruhan sistem dari orang dan organisasi, pengetahuan, proses dan perangkat-perangkat yang kemudian menciptakan benda dan mengoprasikannya. Manusia telah menciptakan teknologi untuk memuaskan keinginan dan kebutuhannya. Banyak dari teknologi modern ialah produk dari sains dan teknik.

3. Teknik merupakan pengetahuan tentang desain dan penciptaan benda buatan manusia dan sebuah proses untuk memecahkan masalah. Teknik memanfaatkan konsep dalam sains, alat-alat teknologi dan matematika.

4. Matematika adalah studi tentang pola dan hubungan antara jumlah, angka, dan ruang. Matematika digunakan dalam sains, teknologi dan teknik.

Pendidikan STEM memberi pendidik peluang untuk menunjukkan kepada peserta didik mengenai konsep, prinsip, dan teknik dari sains, teknologi, rekayasa, dan matematika yang diterapkan secara terintregasi dalam pengembangan produk, proses, dan sistem yang digunakan dalam kehidupan sehari-hari. Pembelajaran berbasis STEM peserta didik menggunakan sains, teknologi, rekayasa, dan matematika dalam konteks nyata yang menghubungkan antara sekolah, dunia kerja, serta dunia global, guna mengembangkan literasi STEM yang diharapkan peserta didik mampu bersaing dalam era ekonomi baru yang berbasis pengetahuan. Pendidikan intregasi STEM tidak hanya fokus mengembangkan kemampuan peserta didik di bidang sains, teknologi, rekayasa/desain dan matematika, akan tetapi juga berupaya menumbuhkan soft skill seperti penemuan inovasi baru dalam bidang teknologi untuk memecahkan suatu masalah.

\section{Model Pembelajaran PjBL}

Menurut Afriana (2015), pembelajaran berbasis proyek merupakan model pembelajaran yang berpusat pada peserta didik dan memberikan pengalaman belajar yang bermakna bagi peserta didik. Pengalaman belajar peserta didik maupun konsep dibangun berdasarkan produk yang dihasilkan dalam proses pembelajaran berbasis proyek. Global SchoolNet (2000) dalam Nurohman (2019) melaporkan hasil penelitian the AutoDesk Foundation tentang karakteristik PjBL. Hasil penelitian tersebut menyebutkan bahwa PjBL adalah pendekatan pembelajaran yang memiliki karakteristik sebagai berikut:

a. Peserta didik membuat keputusan tentang sebuah kerangka kerja

b. Adanya permasalahan atau tantangan yang diajukan kepada peserta didik

c. Peserta didik mendesain proses untuk menentukan solusi atas permasalahan atau tantangan yang diajukan

d. Peserta didik secara kolaboratif bertanggungjawab untuk mengakses dan mengelola informasi untuk memecahkan permasalahan

e. Proses evaluasi dijalankan secara kontinyu

f. Peserta didik secara berkala melakukan refleksi atas aktivitas yang sudah dijalankan 
g. Produk akhir aktivitas belajar akan dievaluasi secara kualitatif

h. Situasi pembelajaran sangat toleran terhadap kesalahan dan perubahan

Proses pembelajaran PjBL STEM dalam membimbing siswa terdiri dari lima langkah, setiap langkah bertujuan untuk mencapai proses secara spesifik. Berikut ini tahapan dalam proses pembelajaran PjBL STEM yang efektif (Laboy-Rush, 2010).

Tahap 1: Reflection

Tujuan dari tahap pertama untuk membawa siswa ke dalam konteks masalah dan memberikan inspirasi kepada siswa agar dapat segera mulai menyelidiki/investigasi. Fase ini juga dimaksudkan untuk menghubungkan apa yang diketahui dan apa yang perlu dipelajari.

Tahap 2: Research

Tahap kedua adalah bentuk penelitian siswa. Guru memberikan pembelajaran sains, memilih bacaan, atau metode lain untuk mengumpulkan sumber informasi yang relevan. Proses belajar lebih banyak terjadi selama tahap ini, kemajuan belajar siswa mengkonkritkan pemahaman abstrak dari masalah. Selama fase research, guru lebih sering membimbing diskusi untuk menentukan apakah siswa telah mengembangkan pemahaman konseptual dan relevan berdasarkan proyek.

Tahap 3: Discovery

Tahap penemuan umumnya melibatkan proses menjembatani research dan informasi yang diketahui dalam penyusunan proyek. Ketika siswa mulai belajar mandiri dan menentukan apa yang masih belum diketahui. Beberapa model dari STEM PjBL membagi siswa menjadi kelompok kecil untuk menyajikan solusi yang mungkin untuk masalah, berkolaborasi, dan membangun kerjasama antar teman dalam kelompok. Model lainnya menggunakan langkah ini dalam mengembangkan kemampuan siswa dalam membangun habit of mind dari proses merancang untuk mendesain.

Tahap 4: Application

Pada tahap aplikasi tujuannya untuk menguji produk/solusi dalam memecahkan masalah. Dalam beberapa kasus, siswa menguji produk yang dibuat dari ketentuan yang ditetapkan sebelumnya, hasil yang diperoleh digunakan untuk memperbaiki langkah sebelumnya. Di model lain, pada tahapan ini siswa belajar konteks yang lebih luas di luar STEM atau menghubungkan antara disiplin bidang STEM.

Tahap 5: Communication

Tahap akhir dalam setiap proyek dalam membuat produk/solusi dengan mengkomunikasikan antar teman maupun lingkup kelas. Presentasi merupakan langkah penting dalam proses pembelajaran untuk mengembangkan keterampilan komunikasi dan kolaborasi maupun kemampuan untuk menerima dan menerapkanumpan balik yang konstruktif. Seringkali penilaian dilakukan berdasarkan penyelesaian langkah akhir dari fase ini.

Menurut (Kurniasih dalam Nurfitriyanti, 2016) Keunggulan penerapan model PjBL yaitu: "(1) meningkatkan motivasi belajar peserta didik untuk belajar mendorong kemampuan mereka untuk melakukan pekerjaan penting, dan mereka perlu dihargai; (2) meningkatkan kemampuan pemecahan masalah; (3) membuat peserta didik menjadi lebih aktif dan berhasil memecahkan problem-problem yang kompleks; (4) meningkatkan kolaborasi: (5) mendorong peserta didik untuk mengembangkan dan mempraktikkan keterampilan komunikasi; (6) meningkatkan keterampilan peserta didik dalam mengelola sumber; (7) memberikan pengalaman kepada peserta didik pembelajaran dan praktik dalam mengorganisasi proyek dan membuat alokasi waktu dan sumber-sumber lain seperti perlengkapan untuk menyelesaikan tugas; (8) menyediakan pengalaman belajar yang melibatkan peserta didik secara kompleks dan dirancang berkembang sesuai dunia nyata; (9) melibatkan para peserta didik untuk belajar mengambil informasi dan menunjukkan pengetahuan yang dimiliki, 
kemudian diimplementasikan dengan dunia nyata; (10) membuat suasana belajar menjadi menyenangkan, sehingga peserta didik maupun pendidik menikmati proses pembelajaran" .

\section{Berpikir Kreatif}

Berpikir kreatif merupakan kegiatan mental yang menghasilkan sesuatu yang baru hasil dari pengembangan. Hal ini sesuai dengan pendapat Coleman dan Hammen (Sukmadinata, 2004) bahwa "Berpikir kreatif adalah suatu kegiatan mental untuk meningkatkan kemurnian (originality) dan ketajaman pemahaman (insight) dalam mengembangkan sesuatu (generating)". Kemampuan berpikir kreatif berkenaan dengan kemampuan menghasilkan atau mengembangkan sesuatu yang baru, yaitu sesuatu yang tidak biasa yang berbeda dari ide-ide yang dihasilkan kebanyakan orang. Menurut Munandar (2009), kemampuan berfikir kreatif dapat diukur dengan indikator-indikator kemampuan berfikir kreatif terbagi menjadi empat hal, yaitu :

1. Kelancaran (fluency), adalah kemampuan untuk menghasilkan banyak gagasan dalam menyelesaikan masalah, memberikan banyak cara atau saran untul melakukan berbagai hal, bekerja lebih cepat dan melakukan lebih banyak daripada yang lain.

2. Keluwesan (flexibility), adalah kemampuan untuk mengemukakan bermacam-macam pemecahan atau jawaban terhadap masalah, dapat melihat suatu masalah dari sudut pandang yang berbeda-beda, dan menyajikan suatu konsep dengan cara yang berbeda.

3. Keaslian (originality), adalah kemampuan untuk mencetuskan gagsan dengan cara-cara yang asli, tidak klise, dan jarang diberikan kebanyakan orang.

4. Elaborasi (elaboration), adalah kemampuan mengembangkan atau memperkaya suatu situasi atau gagasan orang lain sehingga menjadi lengkap dan meningkatka kualitas gagasan tersebut, dan merincinya secara detail yang didalamnya terdapat berupa tabel, grafik, gambar, model dan kata-kata.

Menurut Worthington (2006), mengukur kemampuan berpikir kreatif siswa dapat dilakukan dengan cara mengeksplorasi hasil kerja siswa yang merepresentasikan proses berpikir kreatifnya. Sementara menurut McGregor (2007), mengukur kemampuan berpikir kreatif siswa dapat pula dilakukan dengan mendasarkan pada apa yang dikomunikasikan siswa, secara verbal maupun tertulis. Apa yang dikomunikasikan siswa tersebut dapat berupa hasil kerja siswa terkait tugas, penyelesaian masalah, atau jawaban lisan siswa terhadap pertanyaan guru. Pada Tabel 1 dapat dilihat ciri-ciri kemampuan berpikir kreatif

Tabel 1. Ciri-Ciri Kemampuan Berpikir Kreatif

\begin{tabular}{|c|c|}
\hline $\begin{array}{l}\text { Aspek Kemampuan } \\
\text { Berpikir Kreatif }\end{array}$ & Ciri-Ciri \\
\hline \multirow{3}{*}{ Kelancaran (fluency) } & 1) Mencetuskan banyak gagasan, jawaban atau penyelesaian masalah. \\
\hline & 2) Memberikan banyak cara atau saran untuk melakukan berbagai hal. \\
\hline & 3) Selalu memikirkan lebih dari satu jawaban. \\
\hline \multirow{3}{*}{$\begin{array}{l}\text { Keluwesan } \\
\text { (flexibility) }\end{array}$} & 1) Menghasilkan gagasan, jawaban atau pertanyaan yang bervariasi. \\
\hline & 2) Dapat melihat masalah dari sudut pandang berbeda. \\
\hline & 3) Mampu mengubah cara pendekatan atau pemikiran. \\
\hline \multirow[b]{2}{*}{ Keaslian (originality) } & $\begin{array}{l}\text { 1) Mampu melahirkan ungkapan yang baru dan unik yang berbeda dari } \\
\text { yang lain. }\end{array}$ \\
\hline & $\begin{array}{l}\text { 2) Mampu membuat kombinasi-kombinasi yang tak lazim (jarang } \\
\text { diberikan kebanyakan orang) dari bagian-bagian atau unsur-unsur } \\
\text { untuk strategi menyelesaikan masalah. }\end{array}$ \\
\hline \multirow{2}{*}{$\begin{array}{l}\text { Elaborasi } \\
\text { (elaboration) }\end{array}$} & $\begin{array}{l}\text { 1) Mampu memperkaya dan mengembangkan suatu gagasan atau } \\
\text { produk. }\end{array}$ \\
\hline & $\begin{array}{l}\text { 2) Menambah atau merinci detail dari suatu objek, gagasan atau situasi } \\
\text { sehingga menjadi lebih menarik. }\end{array}$ \\
\hline
\end{tabular}




\section{Implementasi STEM dengan Metode Pembelajaran PjBL dalam Mengasah Kemampuan Berpikir Kreatif Matematis Siswa.}

Perkembangan zaman yang begitu pesat telah menuntun kita untuk mempersiapkan diri sebaik mungkin dalam menghadapinya. Salah satunya adalah dengan mempersiapkan generasi penerus yang berliterasi dalam bidang-bidang STEM. Karena dalam bidang pendidikan, pendekatan STEM dapat digunaan untuk mempersiapkan peserta didik supaya mereka mampu berpikir kreatif, bersaing dan siap untuk bekerja sesuai dengan keahliannya sehingga dapat memberikan inovasi baru. Pembelajaran menggunakan pendekatan STEM secara langsung merupakan cara terbaik dalam memberikan latihan kepada peserta didik untuk dapat mengintegrasikan masing-masing aspek sekaligus.

Deskripsi pembelajaran dengan pengintegrasian pendekatan STEM dengan model PjBL Laboy-Rush dapat diperoleh pengalaman belajar yang mampu mengasah kemampuan berpikir kreatif peserta didik. Hal tersebut digambarkan pada Tabel 2.

\section{Tabel 2. Integrasi STEM dengan Model PjBL untuk Kemampuan Berpikir Kreatif} Siswa

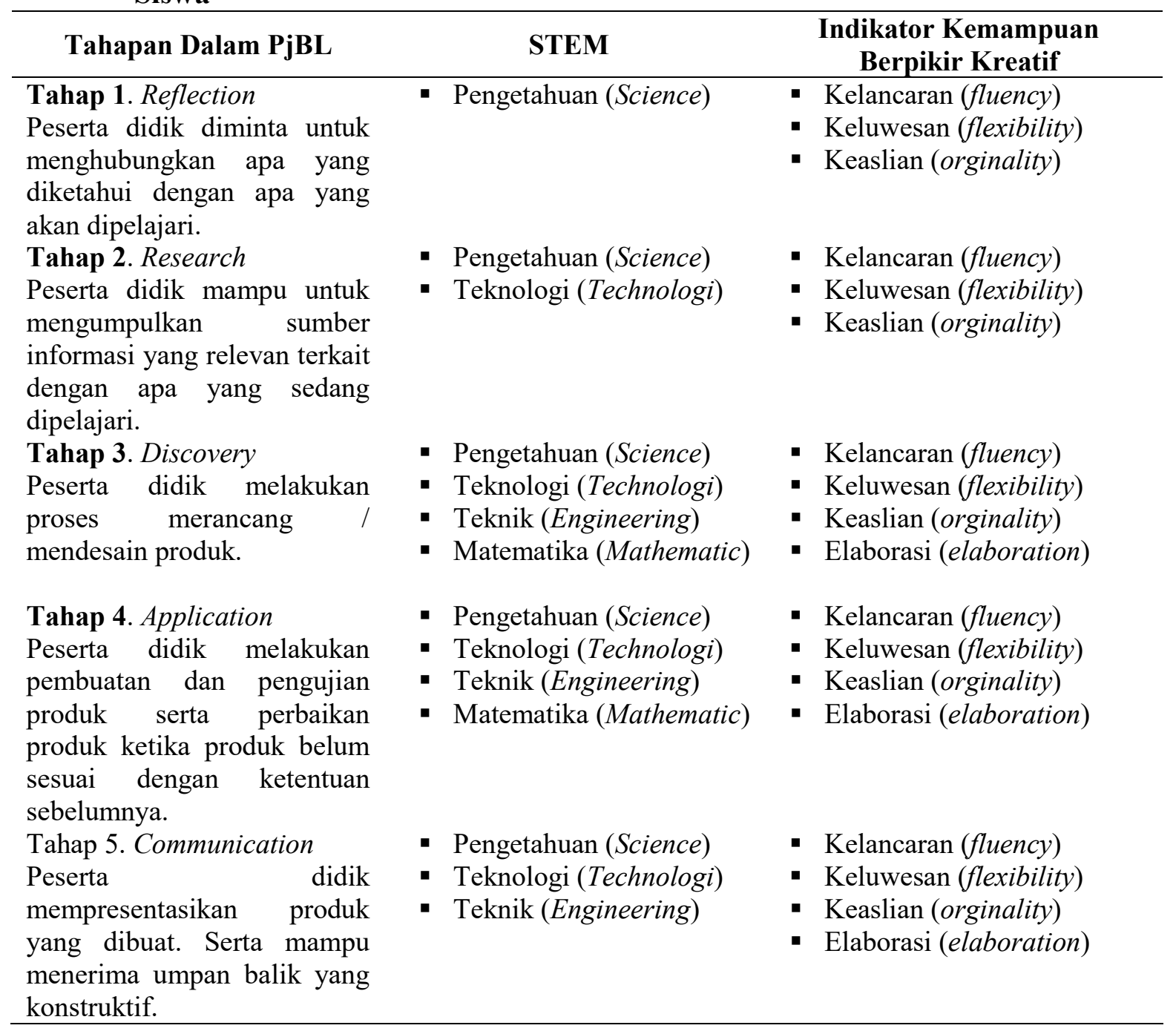

Implementasi pembelajaran STEM menuntun pergeseran pembelajaran dari pembelajaran yang berpusat pada pendidik ke pembelajaran yang berpusat pada peserta didik. Pembelajaran PjBL atau pembelajaran berbasis proyek dapat meningkatkan ketertarikan peserta didik karena keterlibatan peserta didik dalam memecahan masalah yang autentik, bekerja sama dengan kelompok dan membangun solusi atas permasalahan yang nyata. 
Penerapan model PjBL STEM akan sangat menguntungkan karena melibatkan peserta didik untuk berpikir pada permasalahan yang kompleks yang mengasah daya berpikir kreatif mereka. Dalam kajian ini, pembelajaran PjBL STEM digunakan untuk membimbing peserta didik yang setiap langkah bertujuan untuk mencapai proses secara spesifik. Menurut LaboyRush terdapat lima langkah dalam melaksanakan pembelajaran PjBL STEM, antara lain yaitu : (1) reflection, (2) research, (3) discovery, (4) application, dan (5) communication. Melalui pembelajaran dengan langkah-langkah tersebut peserta didik banyak memunculkan kreatifitas dan ketrampilan seperti (manajemen waktu, berkolaborasi dan pemecahan masalah).

Kemampuan kreatifitas dalam menyelesaikan masalah, baik masalah skala besar maupun kecil dapat menentukan kesuksesan individu (Alexander, 2007). Mengingat akan pentingnya kreatifitas pada generasi muda maka hal tersebut sangat perlu ditanamkan dalam setiap pembelajaran. Pembelajaran STEM PjBL memungkinkan peserta didik untuk mengasah kemampuan berpikir kreatifnya. Pada pembelajaran STEM PjBL tersebut peserta didik dapat melatih aspek-aspek berpikir kreatif antara lain yaitu : keluwesan dalam memikirkan berbagai macam cara untuk menyelesaikan masalah atau mampu menyelesaikan permasalahan dari berbagai macam sudut pandang, kelancaran dalam mengungkapkan gagasan, keaslian dalam menciptakan suatu inovasi yang tidak terpikirkan oleh orang lain dan elaborasi atau kemampuan dalam mengembangkan gagasan-gagasan orang lain .

Konsep kerja proyek pada model pembelajaran PjBL dibangun berdasarkan produk yang dihasilan. Disamping itu keberadaan dari pengetahuan, teknologi, teknik dan matematika sangat diperlukan dalam menciptakan proyek/produk yang kreatif. Dengan demikian perpaduan antara pendekatan STEM dengan model PjBL dapat mengoptimalan kegiatan pembelajaran yang mendukung peserta didik dalam mencapai keberhasilan belajar dan ketrampilan berpikir kreatif matematis siswa.

\section{KESIMPULAN}

Pendekatan STEM merupakan pendekatan yang menggabungkan dan mengaitkan empat bidang ilmu yakni pengetahuan, teknologi, teknik dan matematika. Perpaduan antara pendekatan STEM dengan model $\mathrm{PjBL}$ dapat meningkatkan kemampuan berpikir kreatif matematis siswa. Karena pada pendekatan STEM dengan model PjBL siswa dilatih untuk menciptakan pembelajaran berbasis permasalahan kehidupan sehari-hari sehingga dapat melatih siswa dalam menerapan ilmu pengetahuan yang dipelajari di sekolah dengan fenomena yang terjadi dalam dunia nyata. Dengan demikian, pembelajaran berbasis STEM dengan model $\mathrm{PjBL}$ merupakan salah satu pembelajaran yang memiliki potensi digunakan untuk membangun keterampilan abad 21.

\section{DAFTAR PUSTAKA}

Afriana, J. 2015. Project Based Learning (PjBL) Makalah untuk Tugas Mata Kuliah Pembalajaran IPA Terpadu. https://www.researchgate.net/. Diakses 12 November 2019.

Alexander. 2007. Effect Instruction in Creative Problem Solving on Cognition, Creativity, and Satisfaction among Ninth Grade Studenta in an Introduction to Word Agricultural Science and Technology Course. Doctoral dissertation Texas Tech University.

Krippendorff, K. 1993. Analisis Isi : Pengantar Teori dan Metodologi. Jakarta. Citra Niaga Rajawali Press.

Kuhlthau, C.C. 2002. Teaching The Library Research. USA : Scarecrow Press Inc.

Laboy-Rush, D. 2010. Integrated STEM Education Through Project-Based Learning. www.learning.com/stem/whitepaper/integrated-STEM-trough-Project-based-Learning. Diakses 22 November 2019. 
Lestari, T. 2015. Peningkatan Hasil Belajar Kompetensi Dasar Menyajikan Contoh-Cotoh Ilustrasi Dengan Model Pembelajaran Project Based Learning Dan Metode Pembelajaran Demontrasi Bagi Siswa Kelas XI Multimedia SMK Muhammadiyah Wonosari.Skripsi.Progam Studi Pendidikan Tehnik Informatika Fakultas Tehnik Universitas $N$ Negeri Yogyakarta. https://eprints.uny.ac.id/. Diakses 12 November 2019.

McGregor, D. 2007. Developing Thinking; Developing Learning. Maidenhead: Open University Press.

Munandar, U. 2009. Pengembangan Kreatifitas Anak Berbakat. Jakarta : Rineka Cipta.

National Education Association. 2002. Preparing $21^{\text {st }}$ Century Students for a Global Society: An Educators's Guide to the "Four Cs". http://www.nea.org/assets/docs/A-Guide-toFour-Cs.Pdf. Diakses 24 November 2019.

Nazir. 1988. Metode Penelitian. Jakarta : Ghalia Indinesia.

Honey, M., Pearson, G., \& Schweingruber, H. 2014. STEM Integration in K-12 Education : Status, Prospects, and An Agenda for Research. Washington: The National Academies Press.

Nurfitriyanti, M. 2016. Model Pembelajaran Project Based Learning terhadap Kemampuan Pemecahan Masalah Matematika. Jurnal Formatif, 6(2), 149-160.

Nurohman, S. 2019. Pendekatan Project Based Learning Sebagai Upaya Internalisasi Scientific Method Bagi Mahasiswa Calon Guru Fisika. https://staff.uny.ac.id. Diakses 03 Oktober 2019.

Rhodes, M. 1961. An Analysis of Creativity, in : Isaken (editor), Frontiers of Creativity Research, Beyond the Basic. Buffalo New York : Bearly, Ltd.

Sukmadinata, N. S. 2004. Kurikulum dan Pembelajaran Kompetensi. Bandung : Yayasan Kesuma Karya.

Sutanto, L. 2005. Teori Konseling dan Psikoterapi Perdamaian. Malang. Tesis: UNM.

Syaibani, R. 2012. Studi Kepustakaan (Online). http://repository.usu.ac.id/bitstream. Diakses 14 Juni 2020.

Torlakson, T. 2014. Innovate: A Blueprint for Science, Technology Enginering, and Mathematics in California Public Education. http://www.cde.ca.gov. Diakses 06 Oktober 2019.

Worthington, M. 2006. Creativity Meets Mathematics. https://www.childrensmathematics.net. Diakses 03 Oktober 2019. 